Massachusetts Institute of Technology, both of which have indicated their possible interest in collaborating with the joint research effort.

Pressure to find ways of linking the generic research needs of different companies in the computer industry has increased as the costs of research - both in real terms and as a proportion of revenues - has continued to rise.

A report published in 1979 by a panel of computer scientists established by the National Science Foundation suggested that a foundation should be established to raise funds from electronics companies and distribute them to university research departments for carrying out basic research.

As a step in this direction, the Californiabased Semiconductor Industries Association has established a Semiconductor Research Cooperative (ISRC) to act as a clearing house for companys interested in sponsoring university research. The idea of a separate foundation, however, has remained on the shelf.

Mr William Shaffer, spokesman for the Control Data Corporation which organized the Florida meeting, said last week that the ISRC initiative did not go far enough for the industry and was more limited in scope than the proposal which was discussed in Florida which would embrace not only a range of research activities designed to enhance the production of electronics and semiconductor components - an area in which the United States has lost considerable ground to Japan in recent years - but also provide training and other kinds of assistance to collaborating companies.

Computer manufacturers present at the meeting included Burroughs Corporation, Digital Equipment Corporation, Honeywell Incorporated, Sperry Corporation and Rand Corporation. Among the semiconductor producers were Advanced Micro Devices Incorporated. IBM had been invited to participate but did not attend.

The companies agreed to a general framework for a joint research venture that would embrace both basic and applied research. Such a joint venture will have to avoid conflict with strict American anti-trust laws, which have previously been quoted as a major impediment to collaborative research between different companies in the same industry. The need to "clarify" the application of anti-trust laws to research was one conclusion of an eighteen-month review of domestic policies affecting technological innovation carried out under President Carter; a subsequent report from the Department of Justice, published in November 1980, concluded that "in general, the closer the joint activity is to the basic research end of the research spectrum ... the more likely it is to be acceptable under the anti-trust laws'.

Control Data Corporation says that the outline of its proposals already presented to the Federal Trade Commission has not met with any objections. The company is hoping that, by stressing the intention of MCTE to carry out research rather than produce electronics components, any potential conflict with the anti-trust laws will be minimized.

David Dickson

\section{UK-Romania cooperation}

\section{One-way street}

\section{Bucharest}

The meeting earlier this month of the UK-Romanian Joint Commission on Trade and Technology produced a novel suggestion from the Romanian delegation: the establishment of long-term joint technological research projects. But the suggestion is unlikely to stimulate a positive response from the British side, since attempts at cooperation over the past decade have almost all become bogged down in bureaucracy and delay.

Even the one moderately viable project - the production under licence in Romania of BAC-111 aircraft - has run into difficulties; and hopes that the finished product might be exhibited at this year's Farnborough air show are rapidly fading.

Joint research and development ventures are impeded not simply by the currency problems endemic in all dealings with Eastern Europe but also by the reorganization of Romanian science during the seventies which has been specifically aimed at eliminating dependence on foreign licences and the development of a native technological base. According to Romanian planners, during the past five years, Romanian research has provided some 90 per cent of the new materials and more than 90 per cent of the new technologies put into production. This appears to leave little room for technological flow and exchange.

Romanian-British cooperation is formally of two kinds. Pure research, including exchange scholarships, is handled by an agreement between the Royal Society and the Academy of Romania. The restructuring of Romanian science has, however, reduced the academy's role.

The driving force in Romanian science is now the National Council for Science and Technology, headed by Dr Elena Ceaucescu, wife of the president, and the main research potential is concentrated in ten "Central Research Institutes" whose emphasis is largely on applications. At the height of the reforms, in the mid-1970s, it seemed that fundamental research might vanish altogether in Romania; now, however, 10 per cent of the science budget is allotted to "fundamental research".

Although at the academic level it has been possible over the past few years to arrange some cooperation projects - such as the exchange agreement between the Polytechnic University of Bucharest and the Polytechnic of Central London, the types of programmes that would normally fall within the competence of the joint commission are considerably harder to arrange. A joint seminar, held in Bucharest last May, on problems of energy saving in agriculture was - from the Romanian point of view - highly successful, but the British side is reluctant about a return visit, since they felt the "pooling" of knowledge came almost entirely from the British side.

Romanians involved in such ventures admit the disparity. But such oneside arrangements can never prove satisfactory in the long term to the "donor" partner, particularly when all procedural matters are hamstrung by bureaucracy. For, according to a law of 1974 , any Romanian scientist contacted by a foreigner must report the matter to the relevant ministry. Although a number of prominent scientists say this regulation is a dead letter, the atmosphere of delay and obfuscation is hardly conducive to international cooperation.

Vera Rich

\section{Bio-fund open}

Those wishing to take advantage of the European Community's offer to support research and training in biomolecular engineering should think fast. Applications for research contracts are needed by 15 May, and for training contracts by July.

After a long and arduous gestation period, the EEC sponsorship of biomolecular engineering was looked on as something of a disappointment - "we came out with a mouse", said Vicomte Etienne Davignon, commissioner for research and development in Brussels (Nature 28 January, p.273).

But for all that, there is about 8 million European Currency Units ( $£ 4.5$ million) available, and in the United Kingdom the Department of Industry shows signs of being anxious to alert UK scientists to the possibilities of obtaining EEC support for their work.

Research contracts are available for projects mainly related to agriculture and the safety of genetically manipulated organisms. Training contracts lasting 1 to 2 years from January 1983 cover a wider range of subjects including the development of cloning systems and gene transfer in agriculturally important plants. The commission invites submissions from "employed scientists (including those employed by industries) or unemployed scientists (who recently completed a doctoral thesis or postdoctoral assignment) who have demonstrated their capacity for high level scientific research". Applicants should approach the European Commission, but the Department of Industry will advise UK scientists how to apply.

Charles Wenz 